\title{
Parametric evaluation of the technical object suitability based on analyze the quality of its maintenance and use taking into account the initial conditions
}

\author{
Rafat Grądzki ${ }^{1, *}$ \\ ${ }^{1}$ Bialystok University of Technology, Faculty of Mechanical Engineering, , Wiejska 45C, Bialystok \\ 15-351, Poland
}

\begin{abstract}
In this paper, the comparison of three various technical objects (engines of public transport buses) exploitation research for different initial conditions are presented. Object researches were carried out in 2012 and then repeated in 2013. Gathered operational data is presented in three sets ( 1 - concerning object, 2 - concerning driving conditions, 3 - concerning driver, where set 1 is the collection of diagnostic information $D_{k}$, and sets 2 and 3 are the information about object environment $U$ ) in form of conventional points (experts numerical assessments). Relation between point information of object and point information of environment was described by coupled equations of state (describing relations between operation condition and technical condition including initial conditions for each analyzed exploitation period). That method allows to determine parameters of technical condition $\mathrm{a}_{\mathrm{T}}$ and operation condition $\mathrm{a}_{\mathrm{R}}$ and next, from the course of ат parameter, set of parametrical damage $\mathrm{m}_{T}(\mathrm{t})$ and from course of parameter aR - set of momentary damage $a_{R}(t)$. Thus it is possible to evaluate exploitation, technical and operation conditions of each object (bus engine). Received reliability parameters allows to properly control exploitation and service of particular objects and set of objects (fleet of buses) and its elements.
\end{abstract}

\section{Introduction}

In the process of technical object exploitation occurs the gradual damage (decrease in its exploitation properties and mechanical wear). This damage consists on deregulation, wear and deterioration of its reliability. Hence the importance of constant supervision of the operation condition changes, technical condition changes and reliability changes during service and use of technical objects. $[1 \div 16]$

In this paper, current work on new method of exploitation analysis of object aptitude is explained. This is based on assumption that every information (diagnostic signals - set 1, use signals - set 2, use condition signals - set 3 ) is described in the form of point ratings (numerical assessment by expert in the detailed questionnaire).

Diagnostic signals in form of points were used for the first time in diagnostics of shipbased helicopter SH-2G (USA) [16]. In this method aptitude was analyzed only by summing all the points. Next, obtained value is compared to threshold set by manufacturer (USA). Based on relation between sum of the points and allowed number of points, the machine is qualified for further exploitation or repair.

During researches conducted for this article every diagnostic signal, symptom or expert evaluation, was registered in the questionnaire in point form (which is innovatory). Next, in this paper the experts assessment of the bus operation was used to determine required

*Corresponding author: r.gradzki@pb.edu.pl 
regulation and technical condition parameters from model in form of influencing each other equations of state (including initial conditions) $[6,7,9]$ and subsequently from its courses set of damages that are base for determining reliability characteristics. $[2,8,11,12,14,15]$

Presented practical method of exploitation analysis of object aptitude (operation condition, wear condition, reliability) might be, and partially is, applied to process of servicing technical objects. Such data allows to decide on object further destination (about continuation of its use).

\section{Diagnostic research of technical object and its environment}

The analyzed objects were three various MAN buses exploited in the years 2012 and 2013 in Municipal Transport Company of the City of Bialystok. The aim of the research was to obtain diagnostic signals $\mathrm{D}_{\mathrm{k}}$ concerning condition of objects (data from diagnostician) and data on their environment (expert information from driver).

The examinations were conducted in the following months of the year. Thus, a database for 12 months in the year 2012 and 12 months in the year 2013.

Obtained determined (measurable), probabilistic and heuristic data was divided into two subgroups in line with the method:

- diagnosis signals concerning technical condition $\mathrm{D}_{\mathrm{k}}$

- $\quad$ signals concerning environmental impacts on the object $U$

All measured diagnosis signals $\left(D_{k}\right)$ were obtained from diagnostician: $D_{M 1}$ - average fuel consumption without heating $[1 / 100 \mathrm{~km}] ; \mathrm{D}_{\mathrm{M} 2}$ - average fuel consumption with heating $[1 / 100 \mathrm{~km}] ; \mathrm{D}_{\mathrm{M} 3}$ - fogging value during engine blowout $[1 / \mathrm{m}] ; \mathrm{D}_{\mathrm{M} 4}$ - fogging value during engine operation $[1 / \mathrm{m}] ; \mathrm{D}_{\mathrm{M} 5}$ - peak value of noise level[dB]; $\mathrm{D}_{\mathrm{M} 6}$ - average value of noise level $[\mathrm{dB}] ; \mathrm{D}_{\mathrm{M} 7}$ - value of the braking force on the front axle - left wheel $[\mathrm{kN}] ; \mathrm{D}_{\mathrm{M} 8}$ - value of the braking force on the front axle - right wheel $[\mathrm{kN}] ; \mathrm{D}_{\mathrm{M} 9}$ - percentage difference between $\mathrm{D}_{\mathrm{M} 7}$ and $\mathrm{D}_{\mathrm{M} 8}[\%] ; \mathrm{D}_{\mathrm{M} 10}$ - value of braking force on the rear axle - left wheel $[\mathrm{kN}]$; $\mathrm{D}_{\mathrm{M} 11}$ - value of braking force on the rear axle - right wheel $[\mathrm{kN}]$; $\mathrm{D}_{\mathrm{M} 12}$ - percentage difference between $\mathrm{D}_{\mathrm{M} 10}$ and $\mathrm{D}_{\mathrm{M} 11}[\%] ; \mathrm{D}_{\mathrm{E} 1}$ - clatters; $\mathrm{D}_{\mathrm{E} 2}-$ spontaneous engine stalls (on neutral gear); $\mathrm{D}_{\mathrm{E} 3}-$ engine stalls (during operation); $\mathrm{D}_{\mathrm{E} 4}-$ bus mileage

In order to obtain knowledge about environment from specialists (experts) was developed a detailed questionnaire to communicate with users - bus drivers. This gave information about the quality and conditions of use of the object. [6]

Research was undertaken on group of 20 experts, whose tenure as drivers was at least 5 years. $[6,17,18,19]$. The signals collected were:

$\mathrm{U}_{\mathrm{K} 1}$ - driver's tenure [years]; $\mathrm{U}_{\mathrm{K} 2}$ - number of work hours in month [h]; $\mathrm{U}_{\mathrm{K} 3}$ - driving fluency (braking, accelerating); $\mathrm{U}_{\mathrm{D} 1}$ - number of stops; $\mathrm{U}_{\mathrm{D} 2}$ - route length; $\mathrm{U}_{\mathrm{D} 3}$ - surface and formation; $\mathrm{U}_{\mathrm{P} 1}$ - environment temperature; $\mathrm{U}_{\mathrm{P} 2}-$ wind; $\mathrm{U}_{\mathrm{P} 3}$ - atmospheric pressure; $\mathrm{U}_{\mathrm{P} 4}$ - rainfall.

These signals are of varying physical nature and thus were in each case should be transformed to point value.

The conversion procedure for point values and summarizing tables with importance of information $\mathrm{D}_{\mathrm{ki}}$ and $\mathrm{U}_{\mathrm{i}}$ expressed in expert point weights for assessment of engine and its environment condition in 2012 is presented in the previous article [6].

Table 1 shows the recorded signals $D_{k}$ and $U$ of bus 301 in 2013.

Table 1. Combination of diagnostic and environment signals in physical form.

\begin{tabular}{|c|c|c|c|c|c|c|c|c|c|c|c|c|c|c|c|c|}
\hline \multicolumn{17}{|c|}{ Operation signals -2013 year } \\
\hline $\begin{array}{c}\text { Mont } \\
\mathrm{h}\end{array}$ & Dм1 & Dм2 & Dмз & DM4 & DM5 & Dм6 & DM7 & Dм8 & Dм9 & $\begin{array}{c}\mathrm{D}_{\mathrm{M} 1} \\
\mathbf{0}\end{array}$ & $\begin{array}{c}\mathrm{D}_{\mathrm{M} 1} \\
1\end{array}$ & Dм12 & $\begin{array}{c}D_{E} \\
1\end{array}$ & DE2 & $\begin{array}{c}\mathrm{D}_{\mathrm{E}} \\
\mathbf{3}\end{array}$ & $\mathrm{D}_{\mathrm{E} 4}$ \\
\hline 1 & 37,2 & 37,2 & 0,42 & 0,03 & 96 & 93 & 14 & 14,8 & 5,41 & 16,2 & 15,3 & 5,56 & 1 & 0 & 0 & 243747 \\
\hline 2 & 37,2 & 37,2 & 0,42 & 0,03 & 96 & 93 & 14 & 14,8 & 5,41 & 16,2 & 15,3 & 5,56 & 0 & 0 & 0 & 246125 \\
\hline 3 & 37,2 & 37,2 & 0,42 & 0,03 & 96 & 93 & 14 & 14,8 & 5,41 & 16,2 & 15,3 & 5,56 & 2 & 0 & 0 & 248577 \\
\hline
\end{tabular}




\begin{tabular}{|l|l|l|l|l|l|l|l|l|l|l|l|l|l|l|l|l|}
\hline 4 & 37,2 & 37,2 & 0,42 & 0,03 & 96 & 93 & 14 & 14,8 & 5,41 & 16,2 & 15,3 & 5,56 & 0 & 3 & 0 & 250992 \\
\hline 5 & 37,2 & 37,2 & 0,42 & 0,03 & 96 & 93 & 14 & 14,8 & 5,41 & 16,2 & 15,3 & 5,56 & 1 & 0 & 0 & 253490 \\
\hline 6 & 37,2 & 37,2 & 0,42 & 0,03 & 96 & 93 & 14 & 14,8 & 5,41 & 16,2 & 15,3 & 5,56 & 0 & 0 & 1 & 255855 \\
\hline 7 & 34,1 & 34,1 & 0,47 & 0,05 & 93 & 91 & 12,6 & 13,3 & 5,26 & 14,8 & 14,5 & 2,03 & 0 & 0 & 0 & 258256 \\
\hline 8 & 34,1 & 34,1 & 0,47 & 0,05 & 93 & 91 & 12,6 & 13,3 & 5,26 & 14,8 & 14,5 & 2,03 & 1 & 1 & 0 & 260695 \\
\hline 9 & 34,1 & 34,1 & 0,47 & 0,05 & 93 & 91 & 12,6 & 13,3 & 5,26 & 14,8 & 14,5 & 2,03 & 0 & 0 & 0 & 263183 \\
\hline 10 & 36,2 & 36,2 & 0,45 & 0,03 & 94,4 & 92 & 11,9 & 12,3 & 3,25 & 13,3 & 15,7 & 15,29 & 0 & 0 & 0 & 265524 \\
\hline 11 & 36,2 & 36,2 & 0,45 & 0,03 & 94,4 & 92 & 11,9 & 12,3 & 3,25 & 13,3 & 15,7 & 15,29 & 0 & 3 & 2 & 267835 \\
\hline 12 & 36,2 & 36,2 & 0,45 & 0,03 & 94,4 & 92 & 11,9 & 12,3 & 3,25 & 13,3 & 15,7 & 15,29 & 0 & 0 & 0 & 270190 \\
\hline
\end{tabular}

\begin{tabular}{|c|c|c|c|c|c|c|c|c|c|c|}
\hline \multicolumn{11}{|c|}{ Environment signals - 2013 year } \\
\hline Month & $U_{\mathrm{K} 1}$ & $\mathrm{U}_{\mathrm{K} 2}$ & $U_{K 3}$ & $U_{D 1}$ & $U_{D 2}$ & $U_{\mathrm{D} 3}$ & $U_{P 1}$ & $\mathbf{U}_{\mathbf{P} 2}$ & $\mathrm{UP}_{\mathrm{P} 3}$ & $\mathbf{U}_{\mathbf{P 4}}$ \\
\hline 1 & 4 & 141 & 3 & 4 & 14,6 & 2 & $-2,67$ & 15,91 & 992,30 & little rainfall \\
\hline 2 & 4 & 148 & 3 & 4 & 14,6 & 2 & $-0,03$ & 14,38 & 994,71 & little rainfall \\
\hline 3 & 4 & 151 & 4 & 4 & 14,6 & 2 & 0,19 & 13,37 & 992,98 & little rainfall \\
\hline 4 & 4 & 165 & 4 & 4 & 14,6 & 2 & 11,4 & 8,49 & 995,84 & no significant rainfall \\
\hline 5 & 24 & 165 & 8 & 21 & 9,4 & 1 & 21,61 & 8,19 & 990,74 & no significant rainfall \\
\hline 6 & 24 & 168 & 8 & 21 & 9,4 & 1 & 25,06 & 6,14 & 993,67 & little rainfall \\
\hline 7 & 24 & 153 & 4 & 21 & 9,4 & 1 & 26,41 & 7,79 & 1009,49 & no significant rainfall \\
\hline 8 & 24 & 153 & 4 & 21 & 9,4 & 1 & 26,35 & 6,95 & 1017,16 & no significant rainfall \\
\hline 9 & 24 & 174 & 5 & 21 & 9,4 & 1 & 17,5 & 8,95 & 1012,36 & little rainfall \\
\hline 10 & 24 & 182 & 5 & 21 & 9,4 & 1 & 14,1 & 8,64 & 999,67 & no significant rainfall \\
\hline 11 & 24 & 157 & 5 & 21 & 9,4 & 1 & 7,23 & 8,96 & 993,58 & no significant rainfall \\
\hline 12 & 24 & 153 & 6 & 21 & 9,4 & 1 & 2,70 & 11,97 & 998,91 & no significant rainfall \\
\hline
\end{tabular}

Values of signals UP $1 \div$ UP3 in Table 1 were taken as average values from whole month, whereas values of signal UP4 were most frequently occurring. In Table 2 total number of points were obtained by daily change of observed signals to point values which were subsequently, at the end of the month, summed and divided by number of days in the month.

Based on data from Table 1. and including experts weight [6] point forms of signals were obtained - Table 2 for 2013 year. Data for other two buses was filled analogically.

Table 2. Combination of diagnostic and environment signals in point form.

\begin{tabular}{|c|c|c|c|c|c|c|c|c|c|c|c|c|c|}
\hline \multicolumn{14}{|c|}{ Diagnostic signals in point form - 2013 year } \\
\hline Month & Dм1P & Dм2P & Dмзе & $D_{\text {M4P }}$ & Dм5P & DM6P & Dм7P & Dм8P & DM12P & DE1P & DE2P & DE3P & DE4P \\
\hline 1 & 15 & 15 & 10 & 10 & 5 & 5 & 30 & 30 & 0 & 8 & 0 & 0 & 4 \\
\hline 2 & 15 & 15 & 10 & 10 & 5 & 5 & 30 & 30 & 0 & 0 & 0 & 0 & 4 \\
\hline 3 & 15 & 15 & 10 & 10 & 5 & 5 & 30 & 30 & 0 & 8 & 0 & 0 & 4 \\
\hline 4 & 15 & 15 & 10 & 10 & 5 & 5 & 30 & 30 & 0 & 0 & 8 & 0 & 4 \\
\hline 5 & 15 & 15 & 10 & 10 & 5 & 5 & 30 & 30 & 0 & 8 & 0 & 0 & 4 \\
\hline 6 & 15 & 15 & 10 & 10 & 5 & 5 & 30 & 30 & 0 & 0 & 0 & 12 & 4 \\
\hline 7 & 15 & 15 & 10 & 10 & 5 & 5 & 30 & 30 & 0 & 0 & 0 & 0 & 4 \\
\hline 8 & 15 & 15 & 10 & 10 & 5 & 5 & 30 & 30 & 0 & 8 & 4 & 0 & 4 \\
\hline 9 & 15 & 15 & 10 & 10 & 5 & 5 & 30 & 30 & 0 & 0 & 0 & 0 & 4 \\
\hline 10 & 15 & 15 & 10 & 10 & 5 & 5 & 30 & 45 & 0 & 0 & 0 & 0 & 4 \\
\hline 11 & 15 & 15 & 10 & 10 & 5 & 5 & 30 & 45 & 0 & 0 & 8 & 12 & 4 \\
\hline 12 & 15 & 15 & 10 & 10 & 5 & 5 & 30 & 45 & 0 & 0 & 0 & 0 & 4 \\
\hline
\end{tabular}

\begin{tabular}{|c|c|c|c|c|c|c|c|c|c|c|}
\hline \multicolumn{11}{|c|}{ Environment signals in point form - 2013 year } \\
\hline Month & $\mathbf{U}_{\mathrm{K} 1 \mathrm{P}}$ & $\mathbf{U}_{\mathrm{K} 2 \mathrm{P}}$ & $\mathbf{U}_{\mathbf{K} 3 \mathbf{P}}$ & $U_{D 1 P}$ & $U_{D 2 P}$ & $\mathrm{U}_{\mathrm{D} 3 \mathrm{P}}$ & $\mathbf{U}_{\mathbf{P} 1 \mathrm{P}}$ & UP2P & $U_{\mathbf{P} 3 \mathbf{P}}$ & UP4P \\
\hline 1 & 3 & 12 & 9 & 4 & 4 & 12 & 2,00 & 1,00 & 1,32 & 2,84 \\
\hline 2 & 3 & 12 & 9 & 4 & 4 & 12 & 2,00 & 1,00 & 1,54 & 2,75 \\
\hline
\end{tabular}




\begin{tabular}{|l|l|l|l|l|l|l|l|l|l|l|}
\hline 3 & 3 & 12 & 9 & 4 & 4 & 12 & 2,00 & 1,03 & 1,39 & 3,03 \\
\hline 4 & 3 & 12 & 9 & 4 & 4 & 12 & 1,60 & 1,00 & 1,57 & 2,27 \\
\hline 5 & 9 & 12 & 9 & 12 & 2 & 6 & 1,71 & 1,00 & 1,23 & 2,32 \\
\hline 6 & 9 & 12 & 9 & 12 & 2 & 6 & 2,07 & 1,00 & 1,43 & 2,53 \\
\hline 7 & 9 & 12 & 9 & 12 & 2 & 6 & 2,16 & 1,00 & 2,00 & 2,06 \\
\hline 8 & 9 & 12 & 9 & 12 & 2 & 6 & 2,26 & 1,00 & 2,13 & 1,84 \\
\hline 9 & 9 & 12 & 9 & 12 & 2 & 6 & 1,33 & 1,00 & 2,13 & 2,67 \\
\hline 10 & 9 & 18 & 9 & 12 & 2 & 6 & 1,13 & 1,00 & 1,77 & 1,57 \\
\hline 11 & 9 & 12 & 9 & 12 & 2 & 6 & 1,77 & 1,00 & 1,37 & 2,23 \\
\hline 12 & 9 & 12 & 9 & 12 & 2 & 6 & 2,00 & 1,00 & 1,68 & 1,77 \\
\hline
\end{tabular}

\section{Algorithm of determining parameters of technical and operation condition of technical object}

Object (engine) in its environment is described by coupled state equations including initial conditions describing relations between technical condition and operation condition $[6,7$, 9]. It should be noticed that, in these equations diagnostic signals $D_{k}$ are environment for operation signals $U$ and operation signals $U$ are environment for diagnostic signals $D_{k}$.

$$
\begin{aligned}
& \frac{d U}{d t}=a_{R} U+b_{R 1} D_{k}+b_{R 0} \\
& \frac{d D_{k}}{d t}=a_{T} D_{k}+b_{T 1} U+b_{T 0}
\end{aligned}
$$

where: $U$ - operation signal; $D_{k}$ - diagnostic signal of the bus; $a_{R}$ - parameter of the usage condition depends primarily on object work and of the object diagnostic signals $\mathrm{D}_{\mathrm{k}}$ impact on it;

$\mathrm{b}_{\mathrm{R} 1}, \mathrm{~b}_{\mathrm{R} 0}$ - the impact of diagnostic signals parameters and initial conditions on its operating status; aT - parameter of the technical condition of the object, which is dependent on diagnostic signals and signals resulting from acting environment; $\mathrm{b}_{\mathrm{T} 1}, \mathrm{~b}_{\mathrm{T} 0}$ - the parameters of interaction between controlling signals (action) and initial conditions on the technical condition of the bus.

Equation (1) and (2) might be written as follows:

$$
\begin{aligned}
& \frac{\Delta U}{\Delta \theta}=a_{R} U+a_{R} \hat{a}_{R 1} D_{k}+a_{R} \hat{a}_{R 0} \\
& \frac{\Delta U}{\Delta \theta}=a_{R}\left(U+\hat{a}_{R 1} D_{k}+\hat{a}_{R 0}\right) \\
& \frac{\Delta D_{k}}{\Delta \theta}=a_{T} D_{k}+a_{T} \hat{a}_{T 1} U+a_{T} \hat{a}_{T 0} \\
& \frac{\Delta D_{k}}{\Delta \theta}=a_{T}\left(D_{k}+\hat{a}_{T 1} U+\hat{a}_{T 0}\right)
\end{aligned}
$$

According to rules of statistical identification $\mathscr{B}_{k}^{\mathcal{L}}=0$ from equations $(2,5,6)$ we obtain:

$$
\hat{a}_{T 1}=\frac{n \sum_{i=1}^{n} D_{k_{i}} U_{i}-\sum_{i=1}^{n} D_{k_{i}} \sum_{i=1}^{n} U_{i}}{n \sum_{i=1}^{n} U_{i}^{2}-\sum_{i=1}^{n} U_{i} \sum_{i=1}^{n} U_{i}}
$$




$$
\hat{a}_{T 0}=\frac{\sum_{i=1}^{n} D_{k_{i}} \sum_{i=1}^{n} U_{i}^{2}-\sum_{i=1}^{n} D_{k_{i}} U_{i} \sum_{i=1}^{n} U_{i}}{n \sum_{i=1}^{n} U_{i}^{2}-\sum_{i=1}^{n} U_{i} \sum_{i=1}^{n} U_{i}}
$$

and ultimately sought parameter of technical condition $\mathrm{a}_{\mathrm{T}}$ :

$$
a_{T}=\frac{\Delta D_{k}}{\frac{\Delta \Theta}{\text { resurs }}\left(D_{k}+\hat{a}_{T 1} U+\hat{a}_{T 0}\right)}
$$

Parameter $\mathrm{a}_{\mathrm{T}}$ characterizes object technical condition and depends on diagnostic signals $\left(D_{k}\right)$ and signals coming from driver's and environment influence as well as initial conditions $\hat{a}_{T 0}$.

According to rules of statistical identification $\mathcal{E}^{\&}=0$ from equation $(1,3,4)$ we obtain:

$$
\begin{gathered}
\hat{a}_{R 1}=\frac{n \sum_{i=1}^{n} D_{k_{i}} U_{i}-\sum_{i=1}^{n} D_{k_{i}} \sum_{i=1}^{n} U_{i}}{n \sum_{i=1}^{n} D_{k_{i}}{ }^{2}-\sum_{i=1}^{n} D_{k_{i}} \sum_{i=1}^{n} D_{k_{i}}} \\
\hat{a}_{R 0}=\frac{\sum_{i=1}^{n} U_{i} \sum_{i=1}^{n} D_{k_{i}}{ }^{2}-\sum_{i=1}^{n} D_{k_{i}} U_{i} \sum_{i=1}^{n} D_{k_{i}}}{n \sum_{i=1}^{n} D_{k_{i}}{ }^{2}-\sum_{i=1}^{n} D_{k_{i}} \sum_{i=1}^{n} D_{k_{i}}}
\end{gathered}
$$

and ultimately sought parameter of the object operation condition $\mathrm{a}_{\mathrm{R}}$ :

$$
a_{R}=\frac{\Delta U}{\frac{\Delta \Theta}{\text { resurs }}\left(U+\hat{a}_{R 1} D_{k}+\hat{a}_{R 0}\right)}
$$

Parameter $a_{R}$ characterizes object operation condition and depends on operation (utility) signals coming from driver action and environment $U$, diagnostic signals $D_{k}$ and initial conditions $\hat{a}_{R 0}$.

Signals $D_{k}$ and $U$ in homogenous point form [6] were transformed to resultant diagnostic signal $\left(\mathrm{D}_{\mathrm{k}}\right)$ and environment $(\mathrm{U})$.

$$
\begin{gathered}
D_{k}=\sqrt{D_{M 1 P}^{2}+D_{M 2 P}^{2}+D_{M 3 P}^{2}+D_{M 4 P}^{2}+D_{M 5 P}^{2}++D_{M 6 P}^{2}+D_{M 7 P}^{2}+D_{1 E P}^{2}+D_{2 E P}^{2}+D_{3 E P}^{2}+D_{4 E P}^{2}} \\
U=\sqrt{U_{K 1 P}^{2}+U_{K 2 P}^{2}+U_{K 3 P}^{2}+U_{D 1 P}^{2}+U_{D 2 P}^{2}+U_{D 3 P}^{2}+U_{P 1 P}^{2}+U_{P 2 P}^{2}+U_{P 3 P}^{2}+U_{P 4 P}^{2}}
\end{gathered}
$$

Using data from Table 2 and equations $1 \div 12$, increases in technical condition described by parameter $\mathrm{a}_{\mathrm{T}}$ and operation (regulation) condition described by parameter $\mathrm{a}_{\mathrm{R}}$ are calculated.

Subsequently $\sum \mathrm{a}_{\mathrm{T}}$ describing level of object wear and $\sum \mathrm{a}_{\mathrm{R}}$ describing resource of proper operation possibility are determined.

In Table 3, row 1 data was implemented from previous year thus allowing determination of parameters $\mathrm{a}_{\mathrm{T}}$ and $\mathrm{a}_{\mathrm{R}}$ starting from February (position no. 3). 
Results of courses of normalized parameters $a_{T}$ and $a_{R}$ changes for bus no. 301 were presented on Figure 1, for bus no. 303 on Figure 4 and for bus no. 304 on Figure 7.

Figure 2 (from 2012 year) and Figure 3 (from 2013) shows monthly changes (increases) values of these parameters values for the bus 301 .

Figure 5 (from 2012 year) and Figure 6 (from 2013) shows monthly changes (increases) values of these parameters values for the bus 303 .

Figure 8 (from 2012 year) and Figure 9 (from 2013) shows monthly changes (increases) values of these parameters values for the bus 304 .

Table 3. Procedure of calculating technical condition and regulation parameters for bus no. 301 in 2012 year [6].

\begin{tabular}{|c|c|c|c|c|c|c|c|c|c|c|c|}
\hline Month & $\begin{array}{c}\text { Operation } \\
\text { time } \theta\end{array}$ & $\theta$ & Dk & U & $\Delta \theta$ & $\Delta D_{K}$ & $\Delta \mathbf{U}$ & ат & $a_{R}$ & $\Delta$ ат & $\Delta \mathrm{ar}_{\mathrm{R}}$ \\
\hline 1 & 213429 & 2200 & 54,28 & 22,98 & 2200 & 54,28 & 22,98 & & & & \\
\hline 2 & 215582 & 2153 & 50,16 & 21,05 & 4353 & 104,44 & 44,03 & 239,16 & 240,28 & & \\
\hline 3 & 217982 & 2400 & 50,32 & 22,52 & 6753 & 154,76 & 66,55 & 223,67 & 222,38 & $-15,49$ & $-17,91$ \\
\hline 4 & 220102 & 2120 & 50,16 & 22,39 & 8873 & 204,92 & 88,93 & 227,26 & 225,99 & 3,59 & 3,61 \\
\hline 5 & 222669 & 2567 & 51,58 & 21,30 & 11440 & 256,49 & 110,24 & 219,59 & 221,95 & $-7,67$ & $-4,04$ \\
\hline 6 & 225125 & 2456 & 50,79 & 24,43 & 13896 & 307,29 & 134,67 & 215,74 & 207,02 & $-3,85$ & $-14,93$ \\
\hline 7 & 227358 & 2233 & 50,79 & 28,70 & 16129 & 358,08 & 163,36 & 217,88 & 194,61 & 2,14 & $-12,41$ \\
\hline 8 & 229758 & 2400 & 50,16 & 23,12 & 18529 & 408,24 & 186,48 & 217,73 & 216,70 & $-0,15$ & 22,09 \\
\hline 9 & 232273 & 2515 & 50,16 & 25,33 & 21044 & 458,40 & 211,81 & 215,63 & 205,59 & $-2,11$ & $-11,11$ \\
\hline 10 & 234571 & 2298 & 50,16 & 25,26 & 23342 & 508,56 & 237,07 & 215,89 & 206,84 & 0,26 & 1,25 \\
\hline \multirow[t]{2}{*}{11} & 236699 & 2128 & 93,20 & 23,35 & 25470 & 601,76 & 260,42 & 159,62 & 219,24 & $-56,27$ & 12,40 \\
\hline & 239047 & 2348 & 91,47 & 23,37 & 27818 & 693,22 & 283,79 & 166,81 & 218,42 & 7,19 & $-0,82$ \\
\hline 12 & 241392 & 2345 & 91,47 & 27,01 & 30163 & 784,69 & 310,81 & 166,77 & 199,93 & $-0,04$ & $\begin{array}{l}-18,48 \\
\end{array}$ \\
\hline
\end{tabular}

Table 4. Procedure of calculating technical condition and regulation parameters for bus no. 301 in 2013 year.

\begin{tabular}{|c|c|c|c|c|c|c|c|c|c|c|c|}
\hline Month & $\begin{array}{l}\text { Operatio } \\
\text { n time } \theta\end{array}$ & $\theta$ & $D_{K}$ & $\mathbf{U}$ & $\Delta \theta$ & $\Delta D_{K}$ & $\Delta \mathbf{U}$ & ат & ar & $\Delta \mathbf{a}_{\mathrm{T}}$ & $\Delta a_{R}$ \\
\hline 1 & 241392 & 2345 & 91,47 & 27,01 & 30163 & 784,69 & 310,81 & 166,77 & 199,93 & $-0,04$ & $-18,48$ \\
\hline 2 & 243747 & 2355 & 50,79 & 20,61 & 32518 & 835,48 & 331,42 & 250,53 & 261,92 & 83,77 & 61,99 \\
\hline 3 & 246102 & 2378 & 50,16 & 20,61 & 34896 & 885,64 & 352,03 & 249,19 & 260,24 & $-1,34$ & $-1,68$ \\
\hline 4 & 248480 & 2452 & 50,79 & 20,64 & 37348 & 936,44 & 372,68 & 244,59 & 254,94 & $-4,60$ & $-5,31$ \\
\hline 5 & 250932 & 2415 & 50,79 & 20,52 & 39763 & 987,23 & 393,20 & 242,99 & 252,92 & $-1,60$ & $-2,01$ \\
\hline 6 & 253347 & 2498 & 50,79 & 22,38 & 42261 & 1038,03 & 415,58 & 230,47 & 239,28 & $-12,52$ & $-13,64$ \\
\hline 7 & 255845 & 2365 & 51,58 & 22,44 & 44626 & 1089,60 & 438,02 & 227,55 & 235,88 & $-2,93$ & $-3,40$ \\
\hline 8 & 258210 & 2401 & 50,16 & 22,45 & 47027 & 1139,76 & 460,47 & 229,43 & 237,92 & 1,89 & 2,04 \\
\hline 9 & 260611 & 2439 & 50,95 & 22,45 & 49466 & 1190,71 & 482,92 & 226,60 & 234,65 & $-2,83$ & $-3,27$ \\
\hline 10 & 263050 & 2488 & 50,16 & 22,46 & 51954 & 1240,87 & 505,38 & 226,95 & 235,00 & 0,35 & 0,35 \\
\hline 11 & 265538 & 2341 & 60,34 & 26,04 & 54295 & 1301,21 & 531,42 & 193,24 & 197,93 & $-33,71$ & $-37,07$ \\
\hline 12 & 267879 & 2311 & 62,04 & 22,38 & 56606 & 1363,25 & 553,80 & 205,76 & 210,65 & 12,52 & 12,72 \\
\hline 13 & 270190 & 2355 & 60,34 & 22,38 & 58961 & 1423,59 & 576,18 & 208,97 & 213,95 & 3,21 & 3,30 \\
\hline
\end{tabular}

First row from Table 4 was taken from year 2012 (last row in Table 4). It gives the opportunity to determine parameters $\mathrm{a}_{\mathrm{T}}$ and $\mathrm{a}_{\mathrm{R}}$ from January 2013 (position no. 2). 

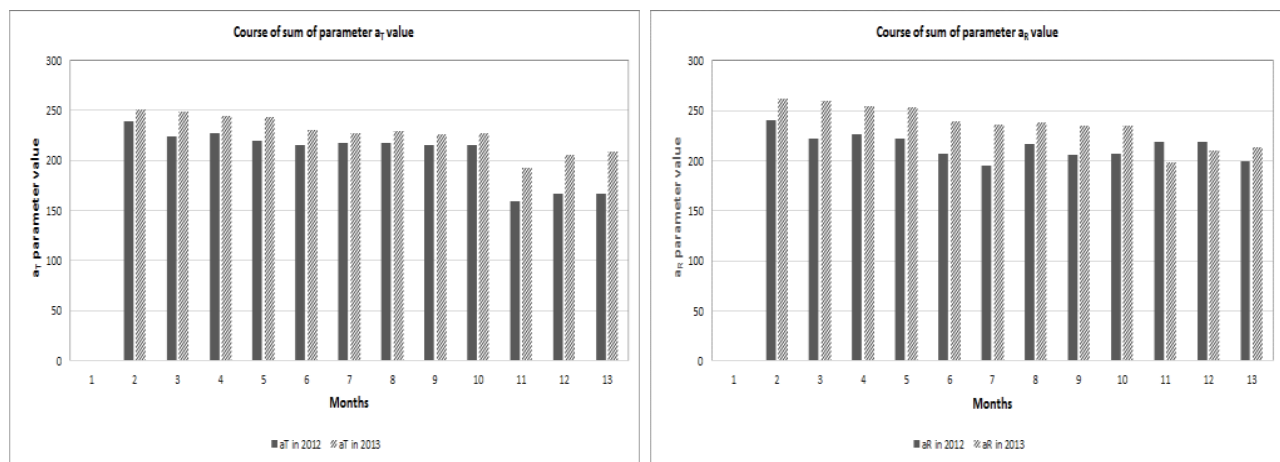

Fig. 1. Changes of normalized parameter of technical condition and regulation for bus no. 301 in year 2012 and 2013.
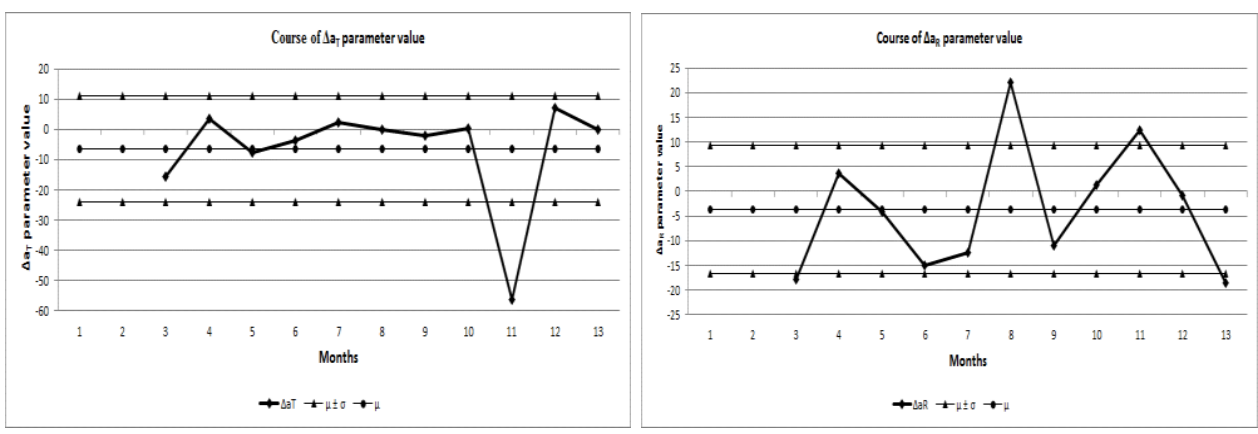

Fig. 2. Course of value of technical condition and regulation parameter increase for bus no. 301 in year 2012 .
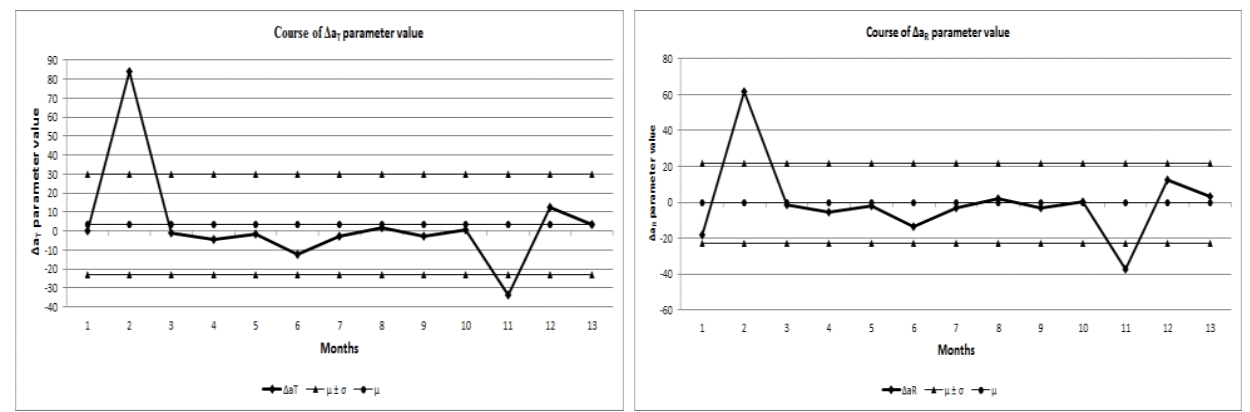

Fig. 3. Course of value of technical condition and regulation parameter increase for bus no. 301 in year 2013.

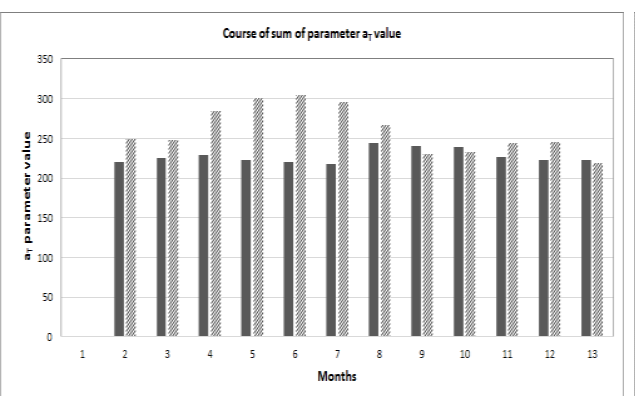

II ait in 2012 \& \& का in 2013

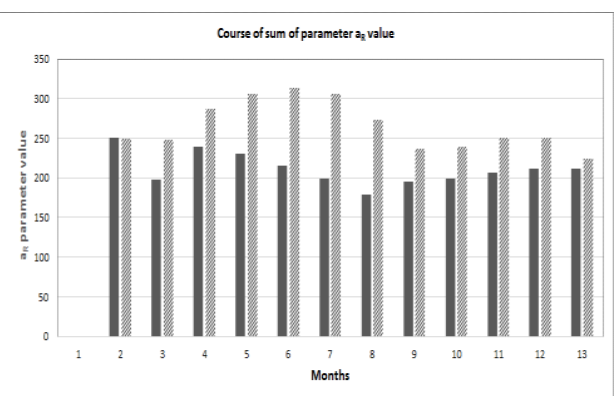

IIER in $2012 \%$ \% 2 in 2013

Fig. 4. Changes of normalized parameter of technical condition and regulation for bus no. 303 in year 2012 and 2013. 

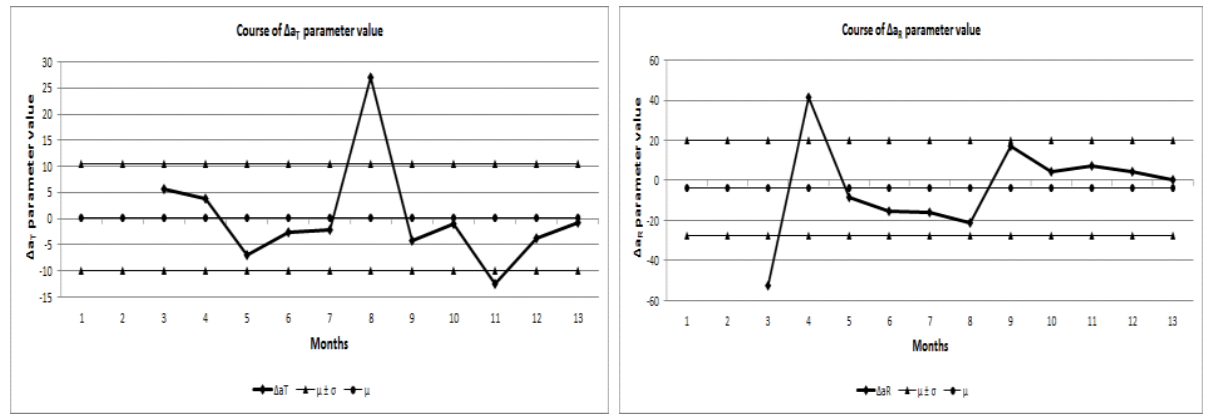

Fig. 5. Course of value of technical condition and regulation parameter increase for bus no. 303 in year 2012.
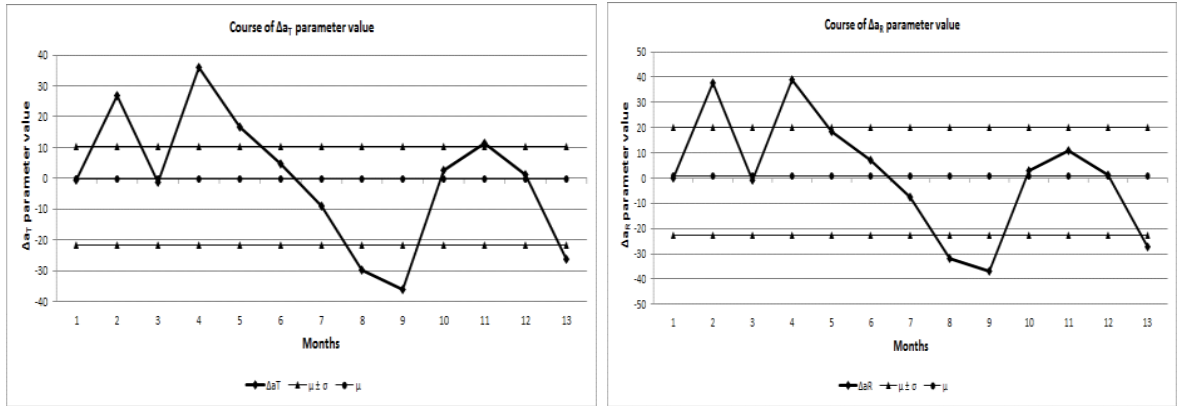

Fig. 6. Course of value of technical condition and regulation parameter increase for bus no. 303 in year 2013.
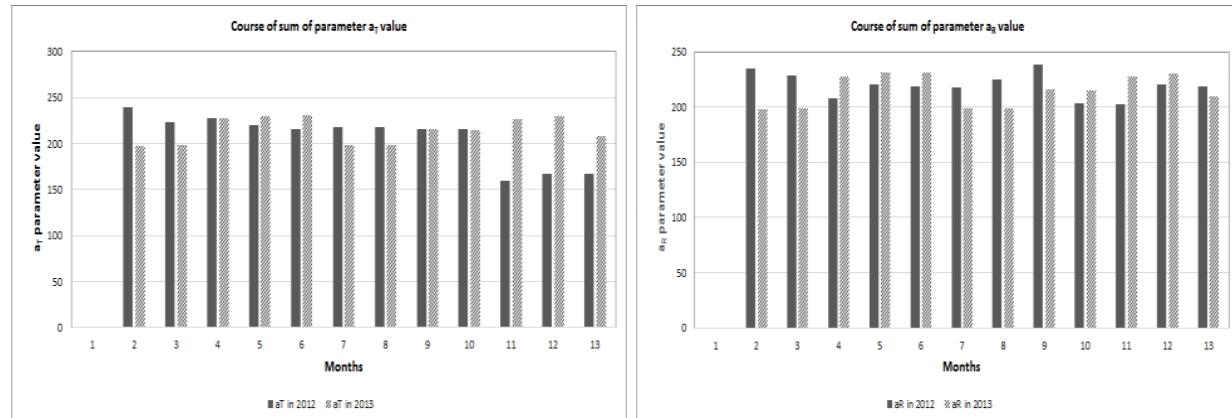

Fig. 7. Changes of normalized parameter of technical condition and regulation for bus no. 304 in year 2012 and 2013.
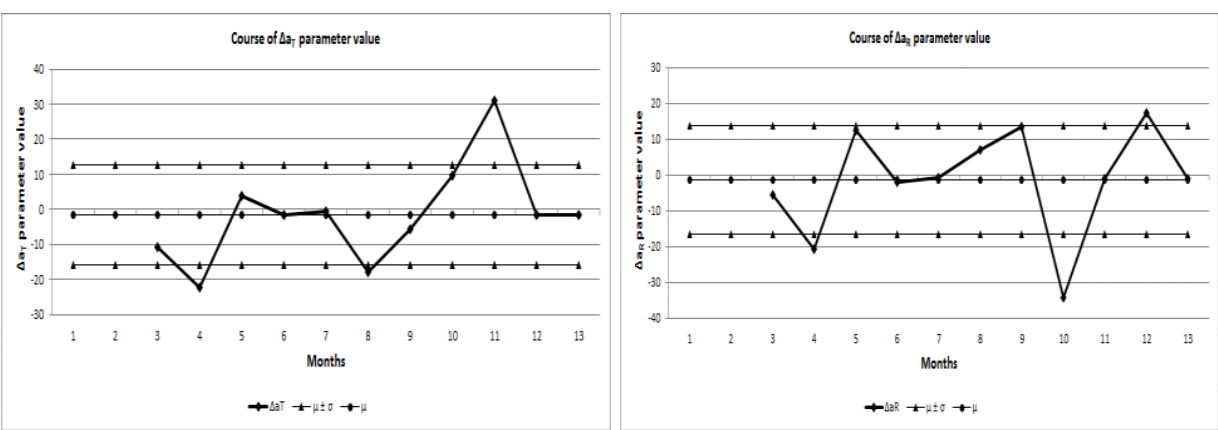

Fig. 8. Course of value of technical condition and regulation parameter increase for bus no. 304 in year 2012. 

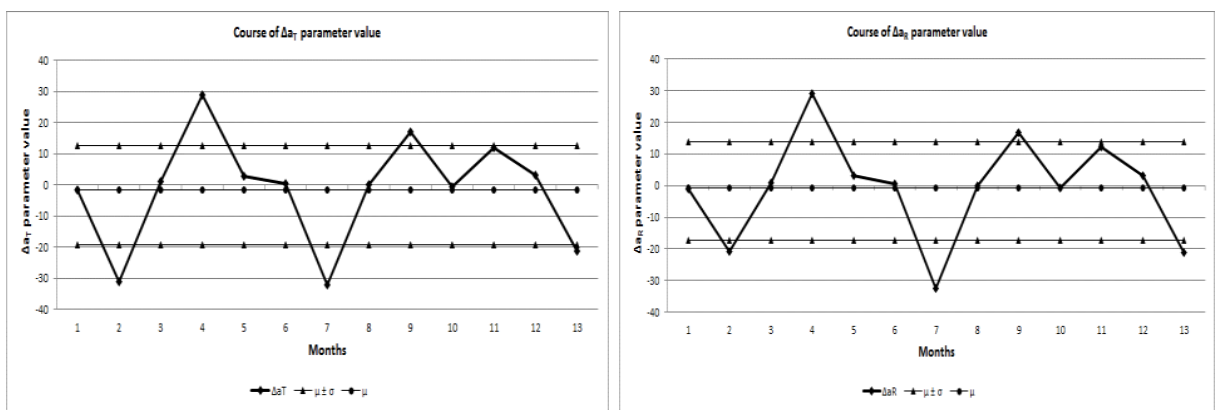

Fig. 9. Course of value of technical condition and regulation parameter increase for bus no. 304 in year 2013.

Table 5. Summary table.

\begin{tabular}{|c|c|c|c|}
\hline Year 2012 & bus no. 301 & bus no. 303 & bus no. 304 \\
\hline sum of aT & 166,77 & 222,40 & 228,44 \\
\hline parametrical damage $\mathrm{m}_{\mathrm{T}}(\mathrm{t})$ & 1 & 2 & 3 \\
\hline sum of aR & 199,93 & 211,03 & 219,00 \\
\hline momentary damage $\mathrm{m}_{\mathrm{R}}(\mathrm{t})$ & 4 & 2 & 3 \\
\hline
\end{tabular}

\begin{tabular}{|c|c|c|c|}
\hline Year 2013 & bus no. 301 & bus no. 303 & bus no. 304 \\
\hline sum of aT & 208,97 & 219,47 & 224,23 \\
\hline parametrical damage $\mathrm{m}_{\mathrm{T}}(\mathrm{t})$ & 2 & 4 & 5 \\
\hline sum of aR & 213,95 & 224,04 & 237,12 \\
\hline momentary damage $\mathrm{m}_{\mathrm{R}}(\mathrm{t})$ & 2 & 6 & 5 \\
\hline
\end{tabular}

On the base of data from Table 3, 4 and charts 1, 4, 7 the following might be noted: the best technical and regulation condition is that of bus no. 301 (2012 year). Values of sum of $\mathrm{a}_{\mathrm{R}}$ and $\mathrm{a}_{\mathrm{T}}$ are the least, thus statement can be made that wear of bus no. 301 is the least and regulation potential was used to the least extent. Its changes in the years 2012 and 2013 are resulting from their use. Buses 303 and 304 (still worse than 301) have improved their performance in 2013 compared to 2012 due to the improvement in operating conditions (more frequent diagnostic tests, better service)

Obtained results were confirmed by discerning analysis of analytical assessments of aptitude of aforementioned buses by direct method realized by experts (diagnosticians drivers in years 2012 and 2013).

Excess of increases values of technical condition and operation condition from the value of standard deviation might be observed in Figures 2, 3, 5, 6, 8, 9. It means that in case when increase of technical condition is greater than standard deviation threshold value, parametrical damage occurred, whereas in case of operation parameter exceeding standard deviation threshold value, momentary damage occurred.

Parametrical and momentary damage do not disqualify object from further exploitation, but may be the base for determining reliability characteristics before the occurrence of dangerous catastrophic damage. The sum the parameters $\mathrm{a}_{\mathrm{T}}, \mathrm{a}_{\mathrm{R}}$ and the number of parametric damages and failures and momentary damages in 2012 and 2013 are shown in Table 5.

The designated number of buses 301, 303 and 304 defects is slightly larger in 2013 than in 2012 year. That means that their condition deteriorates, but these changes are not large. Finally, it can be concluded that all tested buses $(301,303,304)$ may still be safely used. 


\section{Conclusions}

This paper is a continuation of the works contained in [6]. The basis of innovatory method of using varying diagnostic data (in form of points) are presented.

Each change of signal (depending on its value and moment of occurrence) corresponds with number of points predetermined by the experts. So far in such method of aptitude analysis, all the points were summed and subsequently a range was determined in which is the object, its condition and level of exploitation. Proposed method is based on using signals in form of points to determine parameters of regulation and technical condition (equations 9, 12) from coupled state equations [3,5] with initial conditions [3,4] and subsequently reliability and safety of the object during exploitation (Figures 2, 3, 5, 6, 8, 9). The described method may prove to be very useful due to unequivocal presentation of object global exploitation condition using parameters $a_{T}, a_{R}$ and the number of damages $m_{T}(t)$ and $m_{R}(t)$. Thus allows to predict how the object should be used and when the object should be serviced (repaired, overhauled). This method can be especially useful during the operation of the numerous set of objects.

This paper was supported by the research project No. S/WM/1/2016 and financed by the Ministry of Science and Higher Education.

\section{References}

1. L. Bukowski, Prognozowanie niezawodnoś ci i bezpieczeń stwa systemów zautomatyzowanych. Proceedings of the 21st School of Reliability (Szczyrk 2003)

2. C. Cempel, HG. Natke, Damage Evolution and Diagnosis in Operating Systems. Safety Evaluation Based on Identification Approaches Related to Time-Variant and Nonlinear Structures. Springer, pp. 44-61 (1993)

3. J. Filipczyk, Faults of duty vehicles in the aspects of securing safety. Transport Problems, 6, Issue 1, pp. 105-110 (2011)

4. K. Golak, P. Lindstedt, R. Gradzki, Studies of the jet engine control quality based on its response to the disturbance inflicted on the object, designated from its response to the set point inflicted to the controller. In: Safety and Reliability: Methodology and Applications - Proceedings of the European Safety and Reliability Conference, pp: 137-140 (2015)

5. I. Gołda, M. Izdebski, A. Podviezko, Assessment of efficiency of assignment of vehicles to tasks in supply chains: a case study of a municipal company. Transport, 32 Issue 3, pp. 243-251 (2017) https://doi.org/10.3846/16484142.2016.1275040

6. R. Grą dzki, P. Lindstedt, Method of assessment of technical object aptitude in environment of exploitation and service conditions. Eksploatacja i Niezawodnosc Maintenance and Reliability, 1; 54-63 (2015), http://dx.doi.org/10.17531/ein.2015.1.8

7. R. Grą dzki, P. Lindstedt, K. Golak, Premises of evaluation of the technical object suitability with including the quality of its maintenance and operation, and their initial conditions. In: Safety and Reliability: Methodology and Applications Proceedings of the European Safety and Reliability Conference, chapter 44; pp. 319 - 326 (2015)

8. AKS Jardine, D. Lin, D. Banjevic, A review on machinery diagnostics and prognostics implementing condition-based maintenance. Mechanical Systems and Signal Processing, 20, Issue 7, pp. 1483-1510 (2006)

9. P. Lindstedt, T. Sudakowski, The Method of Assessment of Suitability of the Bearing System Based on Parameters of Technical and Adjustment State. Solid State Phenomena Mechatronic systems and materials V, 199 , pp. 73-78 (2013)

10. H. Madej, J. Filipczyk, The methods of assessment of car technical condition regarding environmental protection. Journal of KONES, 16, Issue 2, pp. 103-108 (2009) 
11. T. Nowakowski, Reliability Model of Combined Transportation System. Probabilistic Safety Assessment and Management. Springer, pp. 2012-2017 (2004) http://doi.org/10.1007/978-0-85729-410-4_323

12. H. Sarangaa, J. Knezevicb, Reliability prediction for condition-based maintained systems. Reliability Engineering \& System Safety. Elsevier, 71, Issue 2, pp. 219-224 (2001)

13. J. Rymarz, A. Niewczas, A. Krzyzak: Comparison of operational availability of public city buses by analysis of variance. Eksploatacja i Niezawodnosc Maintenance and Reliability; 18, Issue 3, pp. 373-378 (2016) http://dx.doi.org/10.17531/ein.2016.3.8.

14. J. Rymarz, A. Niewczas, J. Stoklosa, Reliability evaluation of the city transport buses under actual conditions. Transport and Telecommunication, 16, no. 4, pp. 259-266 (2015), DOI 10.1515/ttj-2015-0023

15. E. Zio, Reliability engineering: Old problems and new challenges. Reliability Engineering and System Safety, 94, Issue 2, pp. 125-141 (2009), http://dx.doi.org/10.1016/j.ress.2008.06.002

16. S. Szawłowski, Przeglq d kontrolny ASPA w systemie obsługiwania ś migłowca pokładowego SH-2G. In: AIRDIAG conference Warsaw, Poland, 27-28 October 2005.

17. J. Jaź wiń ski, J. Szpytko, Zasady wyznaczania zespołu ekspertów w badaniach niezawodnoś ci i bezpieczeń stwa urzq dzeń technicznych. XXXIV Zimowa Szkoła Niezawodnoś ci PAN "Niekonwencjonalne metody oceny trwałoś ci i niezawodnoś ci". Szczyrk: pp. 157-167 (2006)

18. M. Woropay, Ł. Muś lewski, M. Ś lę zak, M. Szubartowski, Assessment of the impact of human on safety of transportation system operation. Journal of KONBiN, 1 No. 25, pp. 97-106 (2013)

19. M. Zają c, Wykorzystanie badań ankietowych do oszacowania niezawodnoś ci systemu transportu intermodalnego. XXXIV Zimowa Szkoła Niezawodnoś ci PAN "Niekonwencjonalne metody oceny trwałoś ci i niezawodnoś ci". Szczyrk, 2006. 